\title{
KÁJONI JÁNOS MEGYEI KÖNYVTÁR
}

Kájoni János Megyei Könyvtár

Cím: Csíkszereda, Stadion utca 1/b

Honlap: http://www.konyvtar.hargitamegye.ro

E-mail: info@konyvtar.hargitamegye.ro

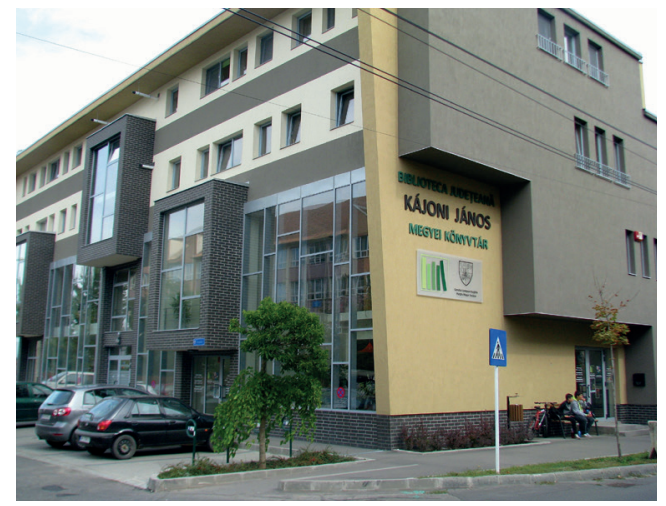

A Kájoni János Megyei Könyvtár Hargita megye legnagyobb közművelődési könyvtára. Hargita Megye Tanácsa által működtetett kulturális, információs, tudományos, oktatási, tájékoztatási és szabadidős központként változatos programokkal szolgálja a megye és Csíkszereda lakosságát. Megyei könyvtárként kiemelt feladatának tekinti a regionális szellemi értékek megőrzését és széleskörű megismertetését. Módszertani központként irányítja, összehangolja a megye közkönyvtárainak tevékenységét. Közel 190000 dokumentumból álló gyűjteményei: könyvek, periodikák, audiovizuális, valamint elektronikus és egyéb dokumentumok képezik sokrétű szolgáltatásainak alapját. Regisztrált könyvtárhasználóinak száma évente több mint 4700, a látogatások száma meghaladja az évi 55 000-et, az évente kölcsönzött dokumentumok száma mintegy 84000.

Csíkszeredában 1950 óta működik városi könyvtár, amely az 1968-as megyésítés után mint megyei könyvtár kapott otthont az új városi múvelődési ház épületében. Az intézmény 2007-ben vette fel Kájoni János, a 17. századi tudós ferencrendi szerzetes nevét, ezzel is jelezve a névadó személyisége által képviselt egyetemes kulturális és emberi értékek szolgálatával való azonosulását.

A könyvtár hamar kinőtte korábbi székhelyét, a megfelelő épület hiánya évtizedeken át gondot jelentett. 2012-ben új székhelyre költözhetett az intézmény; a Stadion utcai új, háromszintes épületben, modern, funkcionális könyvtári terekben, megújult szolgáltatásaival fogadhatja használóit. Nyitott kulturális térként teszi lehetővé különböző

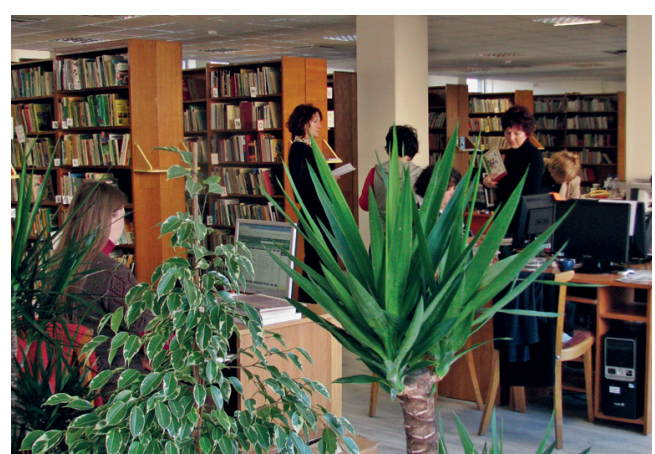




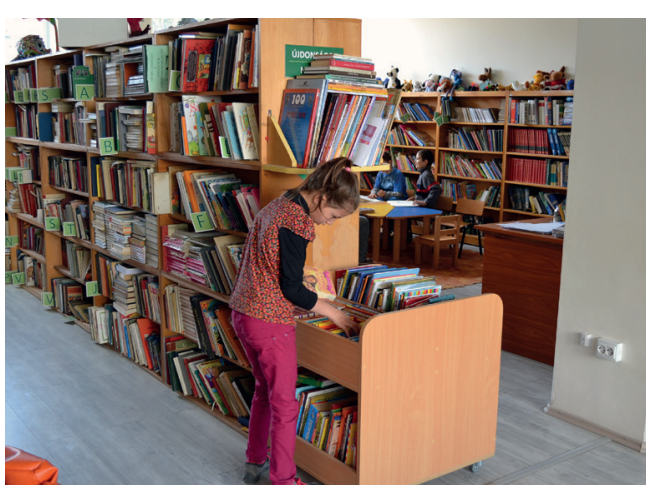

érdeklődésű csoportok és minden korosztály számára, hogy kellemes, kulturált környezetben olvassanak, művelődjenek, tájékozódjanak, tanuljanak, szórakozzanak.

A használók a könyvtár szolgáltatásairól, változatos közösségi- és kulturális rendezvényeiről az intézmény honlapján is tájékozódhatnak. Az online katalógusban saját gyűjteményei mellett más székelyföldi könyvtárak állományában is lehet keresni.

A gyűjtemény értékes, székelyföldi helytörténeti dokumentumait folyamatosan digitalizálják, ezek a digitális dokumentumok is elérhetők a könyvtár honlapjáról. Fontos intézményi célkitűzés a lokális-regionális tartalmak széleskörű közvetítése a könyvtári szolgáltatások révén - a könyvtár honlapjához kapcsolódva érhető el két ilyen lokálisregionális tartalmú online adatbázis is, amelyek folyamatosan bővülnek.

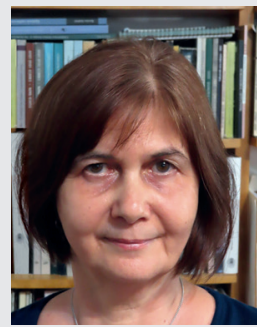

Kelemen Katalin

1990 óta dolgozik a csíkszeredai Kájoni János Megyei Könyvtárban. Egy évig bibliográfusként tevékenykedett, 1991-ben a Helyismeretiés különgyűjtemények gondozását vette át. Könyvtári osztályvezetőként a helyismereti tevékenység mellett munkaköréhez tartozik az intézményi honlap tartalmának frissítése, könyvtári programok, rendezvények szervezése. 2006 óta egyik szerkesztője a Romániai Magyar Könyvtárosok elektronikus hírlevelének, a ReMeK-nek. 